\title{
SOSIALISASI UNMET NEED PASANGAN USIA SUBUR (PUS) DI KELURAHAN MAHARANI KECAMATAN RUMBAI KOTA PEKANBARU
}

\author{
Nelly Karlinah ${ }^{1)}$ Octa Dwienda Ristica ${ }^{2)}$ Novi Ambarwati ${ }^{3)}$ Nursilawati $^{4)}$ \\ 1) STIKes Hang Tuah Pekanbaru \\ email: nellykarlinah87@gmail.com
}

\begin{abstract}
Unmet need is women of childbearing age who are married who do not want to have more children or want to spacing out pregnancies but do not use contraception. The government and the community are responsible for ensuring that every mother has access to quality maternal health services, starting from the time of pregnancy, delivery assistance from trained medical personnel and postpartum maternal care, and access to family planning. Based on the results of the IDHS (2012), it shows that the number of unmet need for contraception in Indonesia is $11.4 \%$. The number of women who want to postpone pregnancy or do not want additional children but do not have family planning increased from 8.6\% (2003) to 9.1\% (2007), and again increased by 11\% in 2012. In 2012 the number of unmet need for KB was high. and affects the value of Total Fertility Rate (TFR) to increase so that the achievement of TFR 2.1 is not achieved. Unmet need for KB apart from being the influence of the success of the TFR is also an effect of the failure of the family planning program which will later continue to be the action of the population in Indonesia, for that it is necessary to increase knowledge through the socialization of Unmeet Need. The Unmet Need socialization was held on 24-27 October 2019 in Maharani Village, Kec. Tassel. This community service is sourced from the DIPA fund of Hang Tuah Pekanbaru, STIKes. The results of the socialization showed an increase in the knowledge of fertile age couples (PUS) about Unmet Need.

Keywords: Unmet Need, Socialization, Fertile Age Couples (PUS).
\end{abstract}

\begin{abstract}
ABSTRAK
Unmet need adalah wanita usia subur yang berstatus kawin yang tidak ingin punya anak lagi atau ingin menjarangkan kehamilan tetapi tidak menggunakan kontrasepsi. Pemerintah bersama masyarakat bertanggung jawab untuk menjamin bahwa setiap ibu memiliki akses terhadap pelayanan kesehatan ibu yang berkualitas, mulai dari saat hamil, pertolongan persalinan dari tenaga medis terlatih dan perawatan pasca persalinan ibu, serta akses terhadap keluarga berencana. Berdasarkan hasil SDKI(2012) menunjukkan bahwa angka unmet needkontrasepsi di Indonesia sebesar 11,4\%. Jumlah PUS yang ingin menunda kehamilan atau tidak menginginkan tambahan anak tetapi tidak ber KB meningkat dari 8,6\% (2003) menjadi 9,1\% (2007), dan kembali meningkat $11 \%$ di tahun 2012. Pada tahun 2012 jumlah unmet needKB menjadi tinggi dan mempengaruhi nilai Total Fertility Rate(TFR) meningkat sehingga pencapaian TFR 2,1 tidak tercapai. Unmet needKB selain sebagai pengaruh keberhasilan TFR juga menjadi pengaruh kegagalan program KB yang nantinya akan berlanjut menjadi tindakan populasi di Indonesia, untuk itu perlu adanya peningkatan pengetahuan melalui sosialisasi Unmeet Need. Sosialisasi Unmet Need ini dilaksanakan pada tanggal 24-27 Oktober 2019 di Kelurahan Maharani, Kec. Rumbai. Pengabdian Kepada Masyarakat ini bersumber dari dana DIPA STIKes Hang Tuah Pekanbaru. Hasil dari sosialisasi didapatkan meningkatnya pengetahuan pasangan usia subur (PUS) tentang Unmet Need.
\end{abstract}

Kata Kunci : Unmet Need, Sosialisasi, Pasangan Usia Subur (PUS). 


\section{PENDAHULUAN}

Angka Kematian Ibu (AKI) merupakan salah satu indikator untuk melihat derajat kesehatan perempuan. Angka kematian ibu menjadi salah satu target ke-tiga Sustainable Development Goals(SDGs) yaitu menjamin kehidupan yang sehat dan mendorong kesejahteraan bagi semua orang di segala usia. Sasarannya untuk menurunkan Angka Kematian Ibu melahirkan hingga 3/4 dari angka pada tahun 1990, sebanyak 450/100.000 kelahiran hidup, maka target SDGs sebanyak 70 per 100.000 pada akhir tahun 2030. Angka Kematian Ibu (AKI) sebesar 359 per 100.000 kelahiran hidup, angka tersebut masih dianggap tinggi (BPS, dkk, 2013). Sementara target pada akhir 2019 sebanyak 306 per 100.000 kelahiran hidup (Kemkes RI, 2015).

Pemerintah bersama masyarakat bertanggung jawab untuk menjamin bahwa setiap ibu memiliki akses terhadap pelayanan kesehatan ibu yang berkualitas, mulai dari saat hamil, pertolongan persalinan dari tenaga medis terlatih dan perawatan pasca persalinan ibu, serta akses terhadap keluarga berencana. Disamping itu, pentingnya melakukan intervensi lebih ke hulu yakni kepada kelompok remaja dan dewasa muda dalam upaya percepatan penurunan
AKI (Kemenkes RI, 2014). Menurut Depkes RI (2010) penyebab langsung kematian ibu di Indonesia diantaranya pendarahan, eklamsia, infeksi, partus lama dan abortus. Sedangkan penyebab tidak langsung yang berperan cukup besar dalam kematian ibu yakni ibu hamil dan melahirkan pada usia rawan $(<20$ tahun atau >35 tahun), terlalu banyak melahirkan anak, terlalu dini atau terlalu rapat melahirkan anak, terbatasnya frekuensi penyuluhan dan pendidikan kesehatan reproduksi juga mempengaruhi kejadian komplikasi persalinan (Enita, 2009). Kebijakan Strategi Peningkatan Kesehatan Ibu untuk mencapai indikator ke tiga target SDGs yakni meningkatkan kesehatan ibu dengan cara menurunkan angka kematian ibu mencapai 70/100.000 kelahiran hidup melalui berbagi macam kegiatan, salah satunya dengan perluasan peserta KB. Dengan KB angka kematian ibu bisa ditekan dari penyebab 4 (empat) terlalu yang ada seperti antara lain terlalu muda, terlalu tua, terlalu banyak, dan terlalu dekat jarak persalinan (Kemenkes RI, 2014).

Unmet need $\mathrm{KB}$ menurut BKKBN merupakan kebutuhan pasangan usia subur untuk ber-KB tetapi kebutuhan itu tidak terpenuhi. Kebutuhan tersebut yakni tidak menginginkan anak lagi atau menjarangkan kelahiran berikutnya tapi pasangan usia subur (PUS) tidak 
menggunakan alat kontrasepsi (Emiherdina, 2011). Ada beberapa faktor yang diperkirakan berpengaruh terhadap masih tingginya Unmet NeedKB antara lain umur, pendidikan,pengetahuan, jumlah anak masih hidup, dukungan suami terhadap $\mathrm{KB}$, pernah pakai $\mathrm{KB}$, aktivitas ekonomi, indeks kesejahteraan hidup, efek samping, dan ketersediaan alat $\mathrm{KB}$, serta keterjangkauannya pelayanan KB.

Unmet needKB merupakan permasalahan yang bersifat multidimensionalkarena dipengaruhi berbagai faktor seperti karakteristik demografi, sosial ekonomi, sikap dan akses pelayanan. Secara umum, unmet needKB banyak terjadi pada wanita yang menghadapi hambatan keuangan, pendidikan, demografis, dan sosial. Berdasarkan hasil SDKI(2012) menunjukkan bahwa angka unmet needkontrasepsi di Indonesia sebesar 11,4\%. Jumlah PUS yang ingin menunda kehamilan atau tidak menginginkan tambahan anak tetapi tidak ber KB meningkat dari 8,6\% (2003) menjadi 9,1\% (2007), dan kembali meningkat 11\% di tahun 2012. Pada tahun 2012 jumlah unmet needKB menjadi tinggi dan mempengaruhi nilai Total Fertility Rate(TFR) meningkat sehingga pencapaian TFR 2,1 tidak tercapai. Unmet needKB selain sebagai pengaruh keberhasilan TFR juga menjadi pengaruh kegagalan program $\mathrm{KB}$ yang nantinya akan berlanjut menjaditindakan populasi di Indonesia (BPS, dkk, 2013).

Penggunaan

kontrasepsi merupakan salah satu upaya dalam Program Keluarga Berencana untuk pengendalian fertilitas atau menekan pertumbuhan penduduk yang paling efektif. Di dalam pelaksanaannya diupayakan agar semua metode atau alat kontrasepsi yang disediakan dan ditawarkan kepada masyarakat memberikan manfaat optimal dengan meminimalkan efek samping maupun keluhan yang ditimbulkan. Dalam pengelolaan pelayanan kotrasepsi di masyarakat pemerintah telah menerapkan kebijakan penggunaan kontrasepsi yang rasional, efektif, dan efisien. Pasien yang mendapat konseling dengan baik akan cenderung memilih alat kontrasepsi dengan benar dan tepat. Pada akhirnya hal itu juga akan menurunkan tingkat kegagalan KB dan mencegah terjadinya kehamilan yang tidak diinginkan. Untuk meraih keberhasilan tersebut, tentunya sangat diperlukan tenaga-tenaga konselor yang profesional. Mereka bukan hanya harus mengerti seluk beluk masalah KB, tetapi juga memiliki dedikasi tinggi pada tugasnya serta memiliki kepribadian yang baik, sabar, penuh pengertian, dan menghargai pasien (Siswanto, 2010). 
Asia Tenggara, Indonesia menempati urutan keempat dengan angka Unmet Need terendah (11\%), tepat di bawah Vietnam (4\%), Thailand (3\%) dan Malaysia. Sementara negara dengan angka unmet need tertinggi ialah Timor Leste (32\%) (Family Planning Worldwide, 2013). Menurut Survei Demografi Kesehatan Indonesia, angka kebutuhan akan KB yang belum terpenuhi (unmet need) di Indonesia sempat mengalami penurunan pada tahun 2007-2012, yaitu dari 13\% menjadi 11\%, namun pada tahun 2015 kembali mengalami peningkatan menjadi $12,70 \%$ (Profil Kesehatan Indonesia, 2016). Angka unmet need tertinggi terjadi di Papua $(29,70 \%)$, Papua $(23,63 \%)$, NTT (21,883\%), Maluku (21,10\%)dan Riau $(16,88 \%)$. Beberapa faktor yang diperkirakan berpengaruh terhadap kejadianunmet need di Indonesia antara lain umur, pendidikan, jumlah anak masih hidup, dukungan suami terhadap $\mathrm{KB}$, pernah pakai $\mathrm{KB}$, aktivitas ekonomi dan indeks kesejahteraan hidup. Unmet need banyak terjadi berkaitan dengan ketakutan terhadap efek samping dan ketidaknyamanan pemakaian kontrasepsi (Kementerian Kesehatan, 2013). Berdasarkan data tersebut selanjutnya BKKBN akan memfokuskan penggarapan KB di 10 provinsi penyangga utama, yakni Sumatera Utara,
Sumatera Selatan, Lampung, Banten, Jawa Barat, Jawa Tengah, DKI Jakarta, Jawa Timur, Nusa Tenggara Timur dan Sulawesi Selatan (BKKBN, 2014).

Hasil Susenas (2015) memperlihatkan adanya peningkatan unmet needKB, kebutuhan KB yang tidak terlayani. Data ini menunjukkan bahwa penurunan Contraceptive Prevalence Rate(CPR) yang terjadi di Indonesia disebabkan oleh peningkatan unmet needKB. Artinya, pelayanan kontrasepsi dan akses PUS terhadap alat kontrasepsi semakin rendah. Peningkatan unmet needuntuk membatasi jumlah anak melonjak dari $8,32 \%$ pada tahun 2014 menjadi 13,02\%. Sementara unmet need $\mathrm{KB}$ untuk mengatur jarak kelahiran naik dari $2,66 \%$ menjadi $5,31 \%$

\section{METODE PENERAPAN}

Metode pengabdian masyarakat ini dilaksanakan dalam bentuk penyuluhan dan metode demonstrasi pada Pasangan Usia Subur (PUS) di Wilayah Kerja Puskesmas Rumbai Bukit kelurahan Maharani Kecamatan Rumbai

\section{HASIL DAN PEMBAHASAN}

\section{A. Hasil Pelaksanaan}

Hasil sosialisasi ini bermanfaat bagi sosialisasi berikutnya untuk 
menambah data dalam meneliti

Faktor-faktor yang Berhubungan dengan terjadinya Unmet Need KB pada Pasangan Usia Subur (PUS) di Wilayah Kerja Puskesmas Rumbai Bukit kelurahan Maharani Kecamatan Rumbai

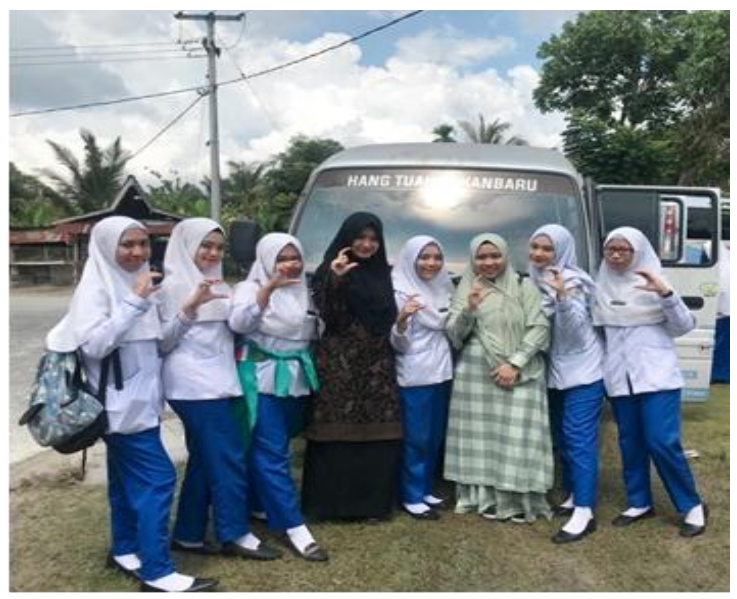

Gambar 1. Penyampaian materi pelatihan SADARI

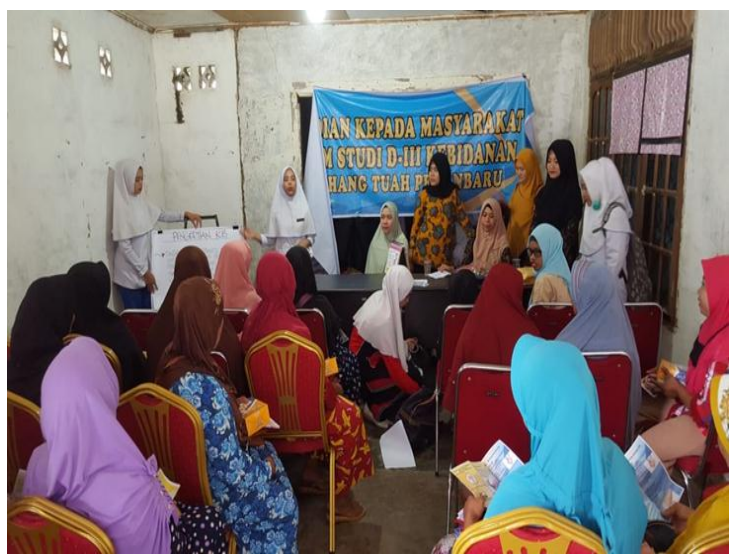

B. Pembahasan

Kegiatan penyuluhan Unmet Need pada Pasangan Usia Subur (PUS) telah dilaksanakan pada " 2427 Oktober 2019 "pada masyarakat PUS di Kelurahan Maharani
Kecamatan Rumbai. Dan pengabdian ini dilakukan untuk pasangan usia subur di Kelurahan Maharani Kecamatan Rumbai.

Berdasarkan pengamatan selama kegiatan berlangsung, kegiatan pegabdian pada masyarakat ini memberikan hasil sebagai berikut :

Meningkatnya pengetahuan dan pemahaman pus untuk memakai alat konntrasepsi dan menjelaskan kegunaan nya.dimana sekarang ini perempuan di Kecamatan Rumbai minim dengan pengetahan alat kontrasepsi, Hal ini dilihat dari hasil pendataan bahwasan nya ibu di Kelurahan Maharani Kecamatan Rumbai minim dengan pengetahuan tentang alat kontrasepsi oleh karna itu kelompok dari Kelurahan Maharani Kecamatan Rumbai ingin memberikan sosialisasi tentang alat kontrasepsi yang bisa untuk memperluas pegetahuan ibu

\section{KESIMPULAN}

Dari kegiatan Pengabdian masyarakat ini dapat disimpulkan bahwa : Pengetahuan Pasangan Usia Subur (PUS) tentang pemakaian alat kontrasepsi meningkat dilihat dengan dapat menjawab pertanyaan

DAFTAR PUSTAKA 
Ashford, Lori. 2003. "Unmet Need for Family Planning: Recent Trends and Their Implications for Programs". www. Measurecommunication.org or www.prb.org Badan Pusat Statistik. 2008b. Laporan Pendahuluan Survei Demografi dan Kesehatan Indonesia 2007. BKKBN, Departemen Kesehatan, Macro Calverton Mary Land.

Badan Penelitian dan Pengembangan Kesehatan. Riset Kesehatan Dasar. 2014. Indonesia: Departemen Kesehatan, Republik Indonesia.

Badan Kependudukan dan Keluarga Berencana Nasional. Rencana Strategis Badan Kependudukan dan Keluarga Berencana Nasional Tahun 2015-2019. Jakarta : BKKBN.

Bhushan, Indhu. 1997. Understanding

Unmet Need. Baltimore: The John Hopkins Schools of Public Health Center for Communication Programs BKKBN. 2002-2003. Survey Demografi dan Kesehatan Indonesia. Jakarta: BPS, BKKBN, DepKes.

Fadhila, Nurul hudha. "Unmed Need Keluarga Berencana Pada Pasangan Usia Subur Di Kecamatan Padang Barat Tahun 2015 " dalam jurnal Kesehatan Masyarakat Andalas. Vol.10, no.2.2016.

Nanlohy, Stesia."Determinan Kejadian Unmet Need Kelurga Berencana Di
Kecamatan Panakkukang Kota Makassar" dalam jurnal Ners dan Kebidanan Indonesia.2016 Ulsafitri, Yellyta dan Fastin, Raisa Nabila. Faktor Yang Berhubungan Dengan Unmet Need KB Pada Pasangan Usia Subur (PUS) Di Kelurahan Tarok Dipo Kecamatan Guguk Panjang Kota Bukittinggi Tahun 2015". 2015.

Westoff and A. Bongke. 1995. "Unmet need 1990 - 1994". DHS Comparative Studies. Institute for Resource Development: Macro International: Colombia.

Westoff and Luis Hernando Ochoa. 1993.

"Unmet Need and Demand for Family Planning". DHS Comparative Studies No. 5. Colombia. 